\begin{tabular}{lll}
\hline VOLUME 1 & No. 3, 22 Desember 2011 & Halaman 213-320 \\
\hline
\end{tabular}

\title{
THE DYNAMIC OF POWER RELATIONS OVER BOMBANA'S GOLD MINING IN SOUTHEAST SULAWESI INDONESIA
}

\author{
Ulil Amri \\ Research Center for Regional Resources, \\ Indonesian Institute of Sciences
}

\begin{abstract}
In mid-2008 a new gold mining site was discovered in Bombana Regency, Southeast Sulawesi, Indonesia. Many people came to the site collectively to do informal mining. Unfortunately, they damaged the surrounding environment, leading the local government to ban their activities. At the same time, the government welcomed companies to invest. However, the miners did not give in. They looked for support from non-governmental organizations and students. These groups worked collaboratively to confront the government, which resulted in violent conflict between the two parties. Each group claimed to have rights over the site, which led them to contest their power with others. Interestingly, according to the main finding of this study, such conflict can potentially become cooperation. This study employed the qualitative method, including semi-structured interviews, study of the literature, and observation.
\end{abstract}

Keywords: power relations, conflict, cooperation, Bombana

\begin{abstract}
ABSTRAK
Sebuah situs tambang emas ditemukan di Kabupaten Bombana, Propinsi Sulawesi Tenggara pada tahun 2008. Banyak orang kemudian berbondong-bondong mendatangi situs tersebut untuk melakukan penambangan informal. Menyikapi hal ini, pemerintah daerah segera memberlakukan larangan kepada mereka karena dianggap merusak lingkungan. Pada saat yang sama, pemerintah membuka pintu pada perusahaan tambang untuk melakukan investasi. Bagaimanapun, para penambang informal ini tidak menyerah. Mereka mencari dukungan pada Lembaga Swadaya Masyarakat dan mahasiswa. Hasilnya, ketiga kelompok ini berkolaborasi untuk melakukan perlawanan terhadap pemerintah yang pada gilirannya menyulut konflik diantara mereka. Tiap-tiap kelompok tampak menunjukkan klaimnya atas situs tersebut sehingga masing-masing mengkontestasikan kuasanya terhadap kelompok lain. Uniknya, sebagaimana hasil studi ini, konflik tersebut berpotensi menjadi kerjasama. Artikel ini merupakan intisari dari penelitian mengenai dinamika relasi kekuasaan di situs tambang emas Bombana yang menggunakan metode kualitatif seperti wawancara semi terstruktur, studi literatur, dan observasi.
\end{abstract}

Kata kunci: relasi kuasa, konflik, kerjasama, Bombana 


\section{INTRODUCTION}

In the mid 2008 a new gold mining site was found in Bombana, a new region in Southeast Sulawesi Province, Indonesia. The quality of its gold is acknowledged as the best one in the country. It is estimated that the site can be explored for about 30 years and can bring prosperity to the whole province. Today, regional government is still waiting to make agreement with mining companies. But, few of them have already arrived for investment such as PT. Panca Logam Makmur and PT. Tiram Indonesia. Meanwhile, the site is being explored by informal miners. They are not only from the region but also from neighbour areas such as Java, Kalimantan, and Papua.

Informal mining is a common activity during the post Indonesian New Order. As a consequence of economic crisis in 1998 which caused high unemployment rate, many people were stimulated to involve in this activity. After the implementation of decentralization in 2001, the number of people work in this sector was doubled. Decentralization enables local people to manage their own resources in order to fulfil their own needs. In terms of mineral resources that previously monopolized by central government, today, the resources are managed by the locals (regional government, people, and traditional landowners). In Bombana's gold mining site, for example, the local people are free to manage the site.

However, this informal mining activity shortly takes regional government's attention because it hampers investment to come. The larger the number of informal miner, the larger areas will be occupied by them. It potentially reduces government revenue. It also damages environment surrounding the site due to uncontrolled tailing of informal mining activities. So far, the government has already imposed several regulations to informal miners such as stopping their activity and giving permit to only mining companies. As a consequence, people take some responses like playing cat and mouse (kucing-kucingan) to hide the government's security forces and conducting mass attack, and protest. Here, I argue that such actions by both government and local people are kinds of power exercise of certain groups over others in order to get control over the gold mining site.

It is interesting then to see the dynamic of power relation of mineral resources among these groups. Therefore, this article aims to see such dynamic in the local context of Bombana region, Southeast Sulawesi, Indonesia by seeing how each group perceives gold mining site's ownership, exercises its power over others to get control over the site, and finds mutual form of relation among the interest groups. This article will be organized as follows. First, it reviews some literatures on the topic of power relation in relation to mining activity. Second, it briefly describes Bombana region since the establishment until got miracle. Third, the article answers the questions above: gold mining site ownership, power relation among interest groups, and the mutual relation form. Finally, this article comes up with conclusion.

\section{DISCUSSION}

Power has been defined by some scholars long time ago. Dahl (1957), a political scientist, for example defined it as certain symbolic manner that is expressed through relation between people. Meanwhile, Foucault (1979), a philosopher, defined it as something which exists everywhere and belongs to everyone. According to him, power works through knowledge, language, and other systems. Based on the two notions above, power relation can be described as certain forms of symbolic manner which exist everywhere and hold by everyone, and expressed through relation among people.

The picture of power relation over gold mining site has existed since the nation came into being. But, the dynamic picture of power relation may exist since Reformasi era which is highlighted by the emergence of massive informal miners. Erman's study (2007) of tin mining in Bangka Island described power relation between government and local 
miners, and within government institutions themselves. Such relation mainly took in a form of contestation for owning, using, and controlling resources. According to her, decentralization enables many actors to get involve in the mining site. Here, the actors are not only central and local governments, but also political parties and companies.

The most significant contestation occurred between regent and governor. After the implementation of Law No. 22/1999, the regency get more power to manage its resources and left the provincial power limited, even smaller than before. As a consequence, conflict is arisen between them. The conflict attracts each supporter to get involve including companies, NGOs, political parties, and local thugs. At the end, the conflict was solved by political action taken by provincial and local parliament. The province finally got right to manage the site because the Law enables them to take action when there is a dispute over the mining site on the regional level (Erman, 2007: 22). Erman's study gave clear picture of how power lies on certain places and wins certain actors over others. Unfortunately, she did not describe how people (informal miners and traditional landowners) play role in that contestation.

A study conducted by Lestari (2007) provided more information about the role of informal miners in political dynamics of the mining site. Her study in Pongkor, West Java showed that the number of informal miners had increased after the downfall of New Order regime. During the time, informal miners almost did not have any space to operate. But, at the early time of Reformasi era, these informal miners got their freedom. Although the company, PT. Antam, collaborated with the local government through its security apparatus in combating the informal miners, their number was not decreased. It was because the informal miners colluded with the apparatus in bribery.

However, the miners' activity brought several impacts on both environment and society. According to Lestari, they damaged 200 hectares of protected park land in the region (Lestari, 2007: 7). The social impacts of informal mining consisted of conflict and crime. The conflict was occurred between informal miners and PT. Antam officials while crime involving the local gangs who attacked local people.

These both impacts attracted government to come back. Under Susilo Bambang Yudhoyono, as Minister of Mining and Energy at the time, the central government exercised its power over local people. He called government and company to seriously tackle the problems. Consequently, the colluding security apparatus were unable to support the miners any longer while informal miners, on the other side, lost their power. Then, the government together with PT. Antam arranged community development program to empower local people especially the ex-miners (Lestari, 2007: 11). What is interesting is this kind of program tended to show another form of power relation called cooperation. It was cooperation because all groups created mutual understanding and fused their interest together in order to achieve better relation.

In the local context of Bombana, the power relation might be more complicated. It does not only involve provincial and regional government in a vis a vis contestation, but also companies, traditional landowners, and the miners as well. Kamil's chronological report (2009) showed the latest picture of Bombana situation. According to her, initially the regional government gave the informal miners rights to operate by issuing government policy (Surat Keputusan Bupati No. 6/2008). However, the rights of informal miners were shortly emasculated after 13 mining companies were given mining permit (Kuasa Pertambangan/KP) not long after the miner's rights were issued. Due to such $\mathrm{KP}$, then the informal miners are banned to operate and chased away from the site. Furthermore, due to such ambiguous policy, traditional landowners, NGOs, the miners as well as companies engage in a contestation. Nonetheless, cooperation is also not impossible. There are some signals which 
indicate that the miners and traditional landowners are ready to get involved in the government scheme. Thus, pure conflict seems to be transformed into a functional type named cooperation. Hence, it is interesting to see these various actors play their own role to control mineral resource in the region and to find out some possibilities to cooperate on the other hand.

There are three types of qualitative method used in this research: (1) semistructured interview. This method employs open-ended questions. There are two types of open-ended questions in this method. First is direct question in which informant directly gives answer; and the next is indirect question in which informant gives argument. Basically, in the semi-structured method informant is given space to discuss, analyze, and articulate the topic based on his or her own thought. Questions for each group are different. In order to deepen the interview, several key informants are interviewed such as local academics and local NGOs activists; (2) it employs literature study. The literature is selected from several relevant sources such as newspapers, magazines, journals, papers, websites, and government reports; (3) This also uses observation to confirm and enrich the data collection and analysis.

\section{\%RP EDQD}

Bombana is a new region of Southeast Sulawesi Province which previously was a part of Buton region. After the massive growth of new regions, following the implementation of decentralization, in 2003 Bombana declared itself as a new region with Rumbia as capital city. This declaration was highlighted with Law No. 29/2003. Geographically, Bombana is acknowledged as a strategic region because of its location closes to Banda Ocean which is known as the strategic area of sea trade. Bombana covers $2.845,36 \mathrm{~km}^{2}$ of land and $11.837,31 \mathrm{~km}^{2}$ of sea which consists of 7 sub-districts. Its population is about 110.029 . The government revenue is mainly gained from local tax while its people's income is primarily from agriculture (paddies, fruits, and vegetables), trade (forest, agriculture, and livestock breeding commodity), and transportation (port of ships) (Southeast Sulawesi Provincial Government 2009).

In 2008, Bombana got miracle. A huge amount of gold deposit was found in the region which estimated about 165,000 tones (Kontan 2008). The deposit was found on two sites: Rarowatu and North Rarowatu sub-district. Rarowatu site is located on an ex-transmigration area namely Sentra Pemukiman Delapan (SP 8). It is a barren land on a hilly area. Meanwhile, North Rarowatu site is located near Tahi Ite River. The distance between these two sites is not far, about 10 kilometres (Muttaqin, 2009).

Soon, the information about the gold mining site spread everywhere. Hundreds of people came to the sites afterwards. They were mainly from neighbor regions like Konawe, North Konawe, Kolaka, North Kolaka, Buton, Muna, and also Kendari municipality. People outside the province also came in a great numbers. Some of them were from Papua, Java, Kalimantan, and also near Sulawesi Island. During several months after the first finding, Bombana had been visited about 20,000 people. "It is a blessing of God", said Nur Alam, the Governor of Southeast Sulawesi Province (Kompas, 2008).

It is a blessing because the site brings benefit to people surrounding. Economically, the miners, at least, got 1 gram per day. It is equal to IDR 200,000 (USD 20). Few miners even got more than that. To do so, they just use simple equipment like hoe, shovel, and frying pan. This amount of money cannot be compared to their income per day without mining. Even the regional minimum salary, IDR 770,000 per month (Indonesian Human Resource Community, 2009), is still lower than that. This economic boom did not only impact local people, but also outsiders. In turn, such boom created multiplier effects.

However, the gold brings social and environmental impacts to the region such as crime, conflict, immorality, environmental degradation, and health problem. In late 
2008, some people reported to local police department that they were suffered by theft, robbery, and deception (Kendari Ekspres, 2008). The chief of local police mentioned that theft and robbery cases were increased in the region currently. The actors often thieved and robbed the miners. Even, the salary of Bombana's local legislators was also stolen. Most of the criminals were from outside region such as Manado (North Sulawesi) and Pare-pare (South Sulawesi). They confessed to commit crimes after being caught by the police officer when they sold fake working permit to the newminers.

Next is conflict. This often happens in any mining site. In Bombana for example, conflict initially occurred between miners and land owners, and then extended to provincial and regional government. Before gold mining site was found, SP 8 and Tahi Ite sites were never in any dispute. But then, the sites have become a conflict source where many interests are contested. Traditional landowners claim that the sites are on their land, so that the sites are also their own. Then, local government does the same claim, arguing that they are the authoritative body to manage the sites. Recently, the miners also ask for their rights.

Gold mining activity also damages environment. According to Kendari Pos (2008), environment surrounding the site had been destroyed. River basin (Daerah Aliran Sungai) was nearly dried so that people could not use the basin any longer to water their farms and gardens. In turn, their harvest was failed due to the decrease of their asset productivity. Also, the water basin had been highly contaminated by mercury $(\mathrm{Hg})$. Rachim (2009) mentioned that water in this gold mining site reached $0.98 \mathrm{mg} /$ liter of mercury. It had exceeded the normal level of mercury use in water which is $0.002 \mathrm{mg}$ / liter.

Due to negative impact stemmed from mining activity which damaged both human and environment, on March 17th 2009, the site was formally closed, except for companies which already got mining KP. From 13 companies, there are two have been operated including PT. Panca Logam Makmur and PT. Tiram Indonesia. Since the operation of these two companies, disputes over gold mining site become enormous, involving all groups in the region including the local government, local people, traditional landowners, companies, local NGOs, and the provincial government as well. Each tries to impose its power over others. But, interestingly at the same time, some of them collaborate each other in a group to strengthen their power.

\section{RZHШ5 HOWRQDUMA] RFDQ HMHO 6WM ZQHUKS $\square$ BHFHSWRQRI DFK * IRXS}

The perception of each group about gold mining site ownership was emerged since the site was firstly found. Miners for example stated that the site should be used for the sake of local people welfare. This indicates that the informal miners are claiming their rights. Such statement has never been voiced out before Reformasi era, especially before the implementation of decentralization in 2001 which guarantees local people's right over resources. Previously, they -most of Indonesian people- did not even know their rights because all mineral resources in their region were just exploited by companies which almost did not give them benefit.

The miners argue that according to Indonesian constitution, mineral and other natural resources must be utilized for the welfare of Indonesian people. Therefore, the site must be for them. They claim that they know how to mine properly, better than company. They also convincingly say that their methods of mining do not harm environment because only using simple or traditional equipments. Unfortunately, they lose their rights after being acquired from SP 8 and SP 7. Recently, due to continuous brute acquisition they migrate to SP 6 . One of miners explained:

We know how to mine without damaging the site. We have our own safety mining techniques since the first phase of mining until reclamation. (Personal Interview, 2009) 
Traditional landowners come up with similar voice. Although they agree that the site is for people, but they emphasize their rights over the site by arguing that the site is on the land of their ancestors inherited it to them. Therefore, they claim to have rights in making decision of how the land should be utilized. Nevertheless, they admit that such rights are not strong enough so that they just want the government acknowledge and involve them in the process of decision making.

As has been known, decentralization gives opportunity for traditional landowners to get involved in the local natural resources' decision making, even though not as decision maker. However, since the opening of Bombana's gold mining site in the mid of 2008 up to its closing, these landowners had not been involved yet. According to the government officials, the reason was there were so many people made claim over the site. All claimed that the land as their own which is inherited from their ancestors. After being verified by an authorized officer to find the real landowners, they were then given 10 percents of the companies' revenue. So far, only PT. Panca Logam Makmur commits to give them revenue.

On the government side, the site is basically for the sake of people's welfare. In order to achieve that, it should be managed properly, professionally, and environmentally friendly. Therefore, the government makes a policy that the site will be managed and operated by company. The reason is that, compared to people, the government can easily control the company. The government ensures that the informal miners will be employed by the company. The government also promises to allocate 25 hectares of the site to informal mining activity. But, it will take times due to do some preparations. One of the regional government official said:

The Law No. 4/2009 guarantes the rights of informal miners to get 25 hectares of the site, but they have to be patient because we (the government) have to ensure that all procedures work properly. I myself even wish that the informal mining area should be extended because 25 hectares are not enough for them. Therefore, I think that the law should be revised to give more hectares to the miners. (Personal Communication, 2009).

Under company management, it is believed that people can be far more prosperous than before and even avoided from negative impact of environmental destruction. So far, PT. Panca Logam Makmur has employed hundreds of informal miners. It claims to have conducted environmental assessment (AMDAL) and given attention to community development by building social facilities to the village around the site like musholla and computers for students. Unfortunately, this company's programs are criticized by the local people because it just hires them as blue collar (pekerja kasar) and the facilities can only be utilized by certain people.

\section{RZHU\&RQWMNRQ}

After the implementation of decentralization policy, region holds more power to manage its own territory than before. This policy gives opportunity for various groups at the regional level to get certain benefit, but rises up regional cost on the other hand. In terms of benefit, many regions, which have abundant natural resources, are becoming more prosperous than before. However, in terms of cost, such regions face certain tensions. To Bombana as a new rich region with 165,000 tons of gold on its land, several disputes emerge involving provincial and regional government, traditional landowners, companies, and miners (local and non local). Each group seems to demonstrate its power over others.

It started when the gold mining site was found and local people began to informally mine the site. Initially, they were free to mine the whole site. Then, regional government announced that such activity must be stopped due to environmental concern. Nevertheless, the miners did not really stop their activity. 
Rather, they played cat and mouse (kucingkucingan). They moved from one to another site or they mine at night in order to avoid the government troops. First, they stayed on SP 8. After being insisted by the army several times, they are settling on SP 6. Based on current information, the army are going to sweep them again. This time, they will be no longer given opportunity to hide.

By the time of sweeping, regional government issued KP to several national companies. The reason is to ensure that mining activity can be controlled. However, not all KP holders can be identified. It has been suspected that few of them are fake as there are only two companies do operate so far. These fake KPs are suspected to be used by the local elites to enrich themselves who rent the KPs to the short term renters. Following this situation, provincial government tried to intervene. However, the intervention was initially hampered by the decentralization law mentioning that the provincial government does not have rights to intervene intra-regional dispute, except inter-regional one. But, after witnessing a serious conflict between the regional government and the miners, finally the provincial government took action. However, the situation became more complicated because some traditional landowners also get involved in the dispute.

Traditional landowners aim to get share from the site by claiming the site as their land. However, according to the regional government, these people just made claim. In fact, some of them have no land at all. It is quite difficult to prove the legality of land without any proof. Therefore, the government just admit few people whom are really acknowledged as traditional landowners after being proven to have strong genealogy with the past Kingdom of Moronene. The government will involve them in decision making process and give them royalty. However, they have not been involved in the decision making process and have not given yet such royalty due to administrative matters. As a result, one of the traditional landowner mentioned:
If both company and government do not give royalty, I will conduct mass demonstration and mobilize all of my family members behind. I have at least nine big families that each of it has at least 30 members.

So far, the mass demonstration had been conducted for several times by the miners. These demonstrations were adressed to PT. Panca Logam Mulia. This company was believed to be the main cause of why the government swept the informal miners. The miners even anarchically attack the company. There were about thousands of people involved in such attack who brought various weapons. To protect the company, hundreds of troops were sent to the site. However, the riot could not be stopped. Two people died at the time. After that incident, more mass protest involving local Non Government Organizations and students were carried out to seek fair solution to the problem.

Such protestors stood on the miners' side. They made a protest because the government stopped informal mining activity and positioned themselves vis a vis the government in order to ensure that the rights of people is counted. They refer to the Law No. 4/2009 which ensuring the people's mining area. Besides that, they also questioned some cases of mis-management on the gold site including KP issuance policy and certain corruption motives behind the policy. The result is positive. The son of the Bombana's regent has already been caught by the police and put in jail. He is accused of corrupting IDR 80 billion. Next, the protesters aimed to investigate the regent whom he also accused of corruption. So far, people are still waiting police and local court to investigate the regent.

Besides conducting protest, the miners also play dumb and mock the government. For example, they mentioned that the government would like to cooperate with company is not because of social and environmental concern, but for the sake of money. Therefore, the government stands on behalf of the company, not people. Furthermore, they said that the armed forces who work under company are 
just like the company's watchdog. They also suspect the company as the most responsible which causes environmental degradation on the region. One of the miners argued that company has used mercury excessively. Hence, he does not believe that the company's existence brings prosperity to Bombana's people because the main interest of the company is solely to get as much money as possbile for itself.

\section{\&RRSHDLRQ [7KH] QGRI_\&RQIOFW}

Besides conflict, interestingly, there is also cooperation which exists among the groups that might end the conflict. In particular, this cooperation is manifested in two forms: negative and positive. So far, such cooperation is still in a negative form. Based on fieldwork data, this form embodied through collusion by the miners, local police officials as well as traditional landowners. When the miners are banned to mine the site, they bribe the police officials with certain amount of money or gold particles (butiran emas) to make sure that they are still able to stay on the site. For those-new minerswho want to enter the site easily can also take this way.

In addition, bribery exists between the miners and traditional landowners. In order to get 'protection', the miners give money to the landowners. According to an informal agreement between them, the miners must give certain amount of revenue taken from their income. This is one of the reasons why many people claim to be traditional landowners. They can simply get short-time benefit just by making claim over land so that the new miners pay and give money. It is easy for the landowners to do this because the miners do not know and do not want to check whether or not these landowners have land certificate.

Cooperation can also be manifested in a positive form which is not impossible to be achieved. For example, the miners mentioned that they actually want to be regulated by the government and have no intention to be anarchic because it will just make them lose job afterwards. However, they ask for justice so that the government treat them well such as giving them proper job in the company with reasonable salary or providing special area to continue informal mining activity. In Lahiri-Dutt's (2009) term, the miners here are asking the government to establish a mining co-management between themselves and the government. In order to ensure their activity is free from using forbidden materials, they are willing to be supervised by the government.

Similarly, the traditional landowners also signal the same message. They mention the possibility of cooperating with the government. They are willing to be regulated by the government and involved in the decision making process. Basically, they realize that the land is constitutionally owned by the state. They also realize that if they clash with the government, they will not get any benefit at all.

\section{CONCLUSION}

It interesting to discuss the dynamic of power relation in Bombana's gold mining site. In a year, the site has had many stories including the good and the bad and has generated various impacts including social, economic, and environment. Each has both positive and negative which in turn bring dynamic picture of it. The most interesting and dynamic story of the site is power relation among various interest groups. On the one hand, each group contests its power over others through conflict but builds a functional form of it on the other. In order to explain the dynamic of power relation over the site comprehensively, three main issues elaborated: perception about the site's ownership, power contestation over the site, and cooperation among the interest groups.

Almost each group claims to own the site. For instance, the informal miners claim that the site must be utilized for the sake of people, as mentioned in the state's constitution. The traditional landowners claim to own the site as the land has already been inherited by their ancestor to them. What 
is interesting here is that these claims would have never been existed without Reformasi and decentralization policy. This policy, in turn, opens space and opportunity for local people to determine their own destiny.

Decentralization also gives opportunity for local people to contest their power over others. In the case of Bombana's gold mining site, for example, the miners attacked the company and conducted mass demonstration together with NGOs and students to protest the regional government's unjust policy. However, the government countered that attack by mobilizing troops which in turn caused the death of two people. This phenomenon may indicate that power relation on the local is still imbalance because the government still becomes a super body whereas people, the miners, are placed underneath.

Interestingly, the conflict comes up with a functional type of it, named cooperation. The miners, for example, want to be supervised by the government as long as they can get job either by given a special area to mine or by being hired as company's employee. Similarly, the traditional landowners are ready to work with the government to manage the site as long as their rights are acknowledged. However, the real challenge in the future is how the government will respond all of these positive signals.

\section{BIBLIOGRAPHY}

Dahl, R. A., 1957, "The Concept of Power," Behavioural Science, 2, 201-215.

Erman, E., 2007, “'Rethinking Legal and Illegal Economy: A Case Study of Tin

Mining in Bangka Island." < Http:// globetrotter.berkeley.edu/ GreenGovernance / papers / Erman2007.pdf>

Foucault, M., (1979). Dicipline and Punish: the Birth of the Prison, New York: Vintage Books.

Indonesian Human Resource Community, 2009, “UMR Sulawesi Tenggara," < http://www.hrcentro.com/umr/ sulawesi_tenggara >

Kamil, S. Y., 2009, “Tambang emas Bombana: berkah atau ancaman?", Jaringan Advokasi Tambang < http://www. jatam.org/content/view/881/21/ >

Kendari Ekspres, 2008, “Kejahatan di tambang Emas Bombana," <http:// kendariekspres.com / index. php?option $=$ com_content\&task $=$ vie $\mathrm{w} \& \mathrm{id}=286 \&$ Itemid $=39>$

Kendari Pos, 2009, “Lokasi pertambangan rakyat dipertanyakan," Kendari Pos 13 August.

Kompas, 2008, "Bombana diserbu Penambang Emas," <http:/ / www.kompas.com/ $\mathrm{read} / \mathrm{xml} / 2008 / 09 / 18 / 21230665 /$ bombana.diserbu.penambang. emas>

Kontan, 2008, "Potensi Emas Bombana 165 Ribu Ton," <http://www. kontan.co.id/index.php/nasional/ news / 1829 / Potensi-Emas Bombana-165-Ribu-Ton>

Lahiri-Dutt, K., 2009, “Viewpoints,” Natural Resource Forum, 33, 245-249.

Lestari, N., 2007, “Illegal gold mining in West Java: can Antam's community development programs win over cynical locals?," Artisanal and SmallScale Mining in Asia-Pacific Case Studies Series, Case Studies No. 3.

Muttaqin, 2009, "<Bayar Dua Gram untuk PSK yang Berparas Cantik," < http:/ / www.kaltimpost.co.id/?mib=berita. detail\&id=12392>

Rachim, 2009, "Maut Merkuri di Tambang Emas Bombana,"< http://www. kabarindonesia.com/berita.ph p? pil $=4 \& j d=$ Maut + Merkuri $+d$ $\mathrm{i}+$ Tambang+Emas+Bombana\& $\mathrm{dn}=20091107125220>$

Southeast Sulawesi Provincial Government, 2009, "Sekilas Kabupaten Bombana," <http:/ / www.sultra.go.id / id/?mod=statik\&show=bombana $>$ 